\title{
Gorlin-Goltz syndrome: a rare case report
}

\author{
Ravi Prakash Sasankoti Mohan, ${ }^{1}$ Sankalp Verma, ${ }^{2}$ Neha Agarwal, ${ }_{1}^{2}$ Udita Singh ${ }^{2}$
}

${ }^{1}$ Department of OMDR, Kothiwal Dental College, Moradabad, Uttar Pradesh, India

${ }^{2}$ Department of Oral Medicine \& Radiology, Kothiwal Dental College \& Research Center, Moradabad, Uttar Pradesh, India

\section{Correspondence to} Dr Ravi Prakash Sasankoti Mohan, sasan_ravi@rediffmail. com

\section{SUMMARY}

Gorlin-Goltz syndrome (GS), also known as nevoid basal cell carcinoma syndrome, is an infrequent multisystem disease inherited in a dominant autosomal way, which shows a high level of penetrance and variable expressiveness. It is characterised by keratocystic odontogenic tumours (KCOT) in the jaw, multiple basal cell nevi carcinomas and skeletal abnormalities. This syndrome may be diagnosed early by a dentist by routine radiographical examinations in the first decade of life, since the KCOTs are usually one of the first manifestations of the syndrome. This article describes an 11-year-old boy with GS.

\section{BACKGROUND}

Gorlin-Goltz syndrome is an infrequent multisystemic disease, that is, characterised by a predisposition to neoplasms and other developmental abnormalities. ${ }^{1}$ It is a hereditary condition inherited in a dominant autosomal way and caused by mutations in the PTCH1 (Patched1) gene which is mapped to the long arm of chromosome $9 \mathrm{q} 22.3-\mathrm{q} 31 .^{1-4}$ The syndrome has received several names throughout the time such as nevoid basal cell carcinoma syndrome, Gorlin syndrome, basal cell nevus syndrome, fifth phacomatosis, multiple basilioma syndrome, hereditary cutaneomandibular polyoncosis and the most complex one 'Jaw-cyst-basal-cell-nevus, bifid rib syndrome.' Diagnosis of Gorlin-Goltz syndrome is made by having two major criteria or one major and two minor criteria. The major criteria includes odontogenic keratocysts of the jaws, more than two sites of basal cell carcinomas or one site of basal cell carcinoma in persons younger than 20 years, three or more palmar or plantar pits, calcification of falx cerebri, bifid or fused ribs, first-degree relative with Gorlin-Goltz syndrome. The minor criteria include macrocephaly, congenital malformations such as cleft lip or palate, frontal bossing, hypertelorism, skeletal abnormalities, vertebral anomalies, ovarian fibroma or medulloblastoma. ${ }^{156}$ During the past few years very important advances have been taking place in the knowledge of the genetic characteristics of this syndrome, existent clinicopathological variants and its different manifestations. ${ }^{1}$ Here we report a rare case of Gorlin syndrome in a 11-year-old boy.

\section{CASE PRESENTATION}

A 11-year-old boy along with his parents had come to our outpatient department with swelling on lower right jaw region since 1 month (figure 1A) which was associated with pain. Medical history was non-contributory. Family history was unremarkable with the absence of consanguinity. General physical examination revealed presence of extra fingers attached to the little ones (figure 1B). Extraoral examination revealed hypertelorism, wide nasal bridge (figure 1A). A diffuse swelling was present on the right cheek region which was firm to hard in consistency and was mildly tender on palpation. Bilateral submandibular lymph nodes were palpable and non-tender. Intraoral examination revealed a diffuse swelling extending mesiodistally from 44 to mesial aspect of 46 teeth region. The overlying mucosa was firm to hard in consistency and was tender on palpation. Taking into consideration the above findings, the patient was subjected to radiographical investigations.

On the basis of clinical history and radiographical findings the case was provisionally diagnosed as Gorlin-Goltz syndrome.

\section{INVESTIGATIONS}

Orthopantomograph revealed multiple radiolucencies present in the right and left maxillary posterior region, and in right mandibular region radiolucency displaces the permanent tooth, that is, 45 towards the right lower border of the mandible (figure 2A).

Occlusal radiograph demonstrating the diffuse radiolucency in the left maxillary posterior region extending towards the mid palatine suture (figure 2B).

Histopathology of the excised epithelium revealed the presence of stratified squamous epithelium with parakeratinisation overlying the connective tissue stroma. The basal cell layer showed the presence of tall columnar epithelium while the connective tissue stroma revealed the presence loosely arranged collagen fibre bundle having spindleshaped fibroblast with presence of satellite cells thereby, confirming the diagnosis of Keratocystic odontogenic tumour (figure 2C).

Overall clinical features, imaging characteristics and histological findings lead to a final diagnosis of Gorlin-Goltz syndrome.

\section{DIFFERENTIAL DIAGNOSIS}

- Multiple myeloma

- Cherubism

- Ameloblastoma

- Bazex syndrome

- Trichoepithelioma papulosum multiplex

- Muir-Torre's syndrome

\section{TREATMENT}

The patient was referred to the department of oral and maxillofacial surgery for the surgical enucleation of the cystic lesions. 
Figure 1 (A-B) Profile photograph of the patient showing hypertelorism, wide nasal bridge with swelling in the right lower jaw region. (C) Physical examination revealed presence of extra fingers attached to the little ones (syndactyly).
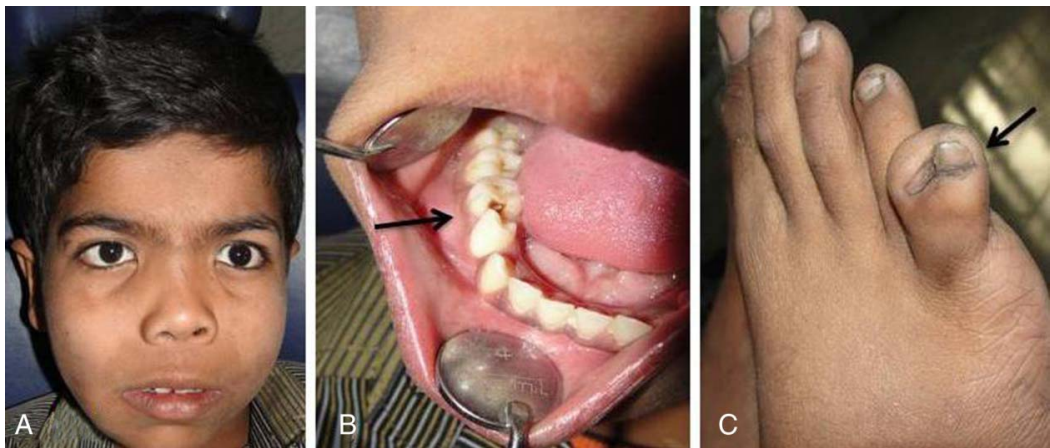

\section{OUTCOME AND FOLLOW-UP}

The prognosis of the current case was good.

\section{DISCUSSION}

In 1894, Jarisch and White made the first description of patients with this syndrome, highlighting the presence of multiple basocellular carcinomas. Later in 1939, Straith described a familiar case in which multiple basocellular carcinomas and cysts appeared. In 1953, Gross presented a case suggesting additional signs such as synostosis of the first left rib and bilateral bifurcation of the sixth ribs. On the other hand, Bettley and Ward were the first to relate the presence of palmar and plantar pits with this syndrome. Nevertheless, it was not until 1960 when Robert James Gorlin and William Goltz established a classical triad that characterises the diagnosis of this syndrome (multiple basocellular epitheliomas, keratocysts in the jaws and bifid ribs). ${ }^{1}$ This triad was later modified by Rayner et al, who established that for giving the diagnosis at least, cysts have to appear in combination with calcification of the falx cerebri or palmar pits. ${ }^{15}$ A multitude of signs, not always present in all the patients and which may vary in their severity and time of onset have been described in this syndrome. Of these, the triad of multiple jaw cysts, multiple basal cell nevi or carcinomas and skeletal anomalies have been a constant finding. ${ }^{13} 7$ in our patient most of the findings were present. A characteristic facial appearance which has been described in this syndrome includes frontal and temporal bossing, well developed supraorbital ridges, ocular hypertelorism, wide nasal bridge, mandibular prognathism, internal strabismus and rotatory nystagmus. ${ }^{7}$ These signs are, however, not a constant finding, as our patient presented with hypertelorism, wide nasal bridge and slight facial asymmetry due to swelling in the right cheek region. The skin lesions found were few brownish flesh-coloured basal cell nevi distributed in the periorbital region, forearm and chest. This finding substantiates Gorlin's observation that in this syndrome, basal cell nevi differ from basal cell carcinomas by their appearance at a younger age. ${ }^{7}$ Other associated skin manifestations include palmar pits. Many skeletal anomalies include bifid ribs, fused vertebrae, scoliosis, polydactyly, short fourth metacarpals, sprengel deformity. ${ }^{48}$ Of these, our patient demonstrated syndactyly of little finger. Some authors have previously mentioned the association of ovarian calcification, ovarian cysts and ovarian fibroma with this syndrome. ${ }^{78}$ These were absent in our case. Chromosomal studies indicate that the syndrome is familial and is inherited as an autosomal dominant with high penetrance; however, sporadic cases do occur. ${ }^{7} 910$ Although no such
Figure 2 (A) Orthopantomograph revealed multiple radiolucencies present in the right and left maxillary posterior region, and in right mandibular region radiolucency displaces the permanent tooth, that is, 45 towards the right lower border of the mandible. (B) Occlusal radiograph demonstrating the diffuse radiolucency in the left maxillary posterior region extending towards the mid-palatine suture. (C) Photomicrograph of H\&E stained histopathological section showing features suggestive of keratocystic odontogenic tumour (original magnification: $\times 40$ ).
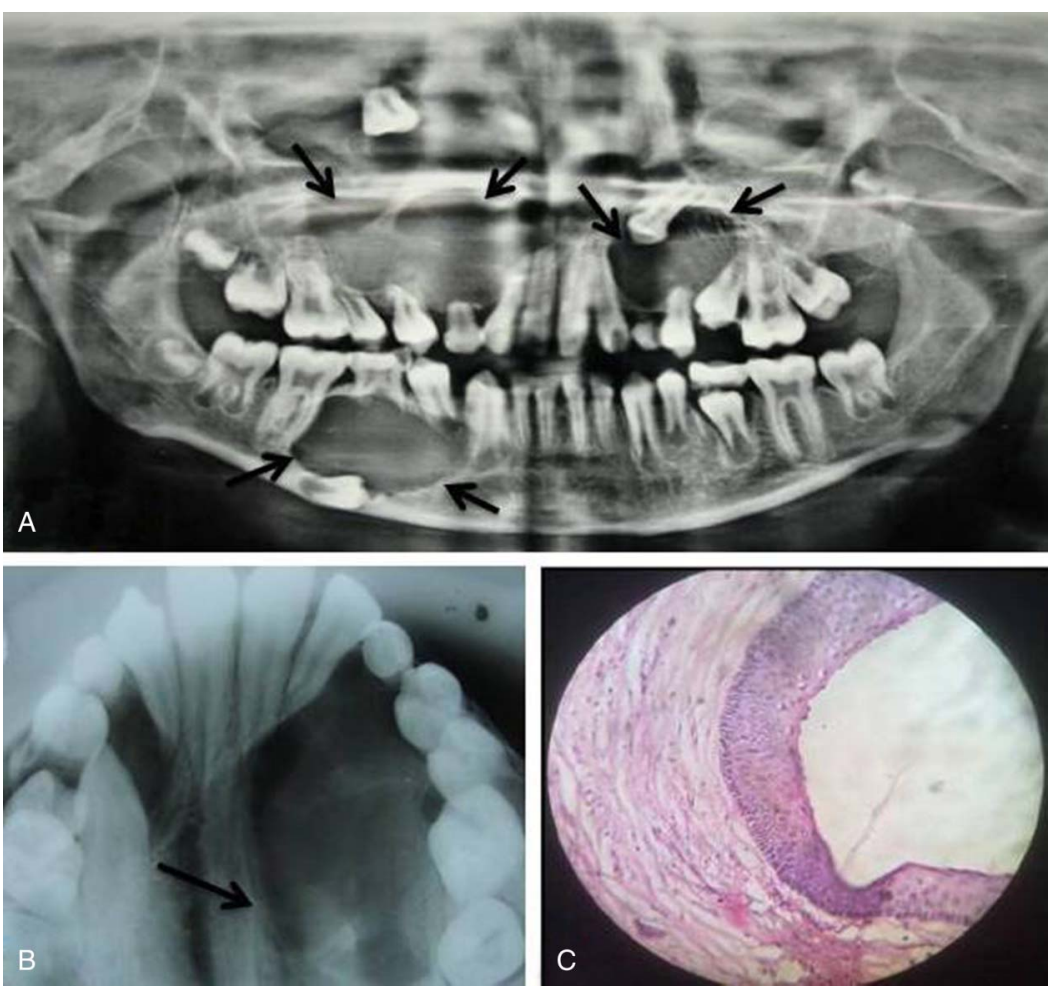
studies were undertaken in our patient, he was probably a sporadic case since his parents and the siblings examined, showed no abnormality. Individuals with no known affected family members may comprise upto $60 \%$ of all affected individuals. ${ }^{2} 10$ The prevalence of Gorlin-Goltz syndrome has been estimated about 1 in $60000 .^{19}{ }^{10}$ Some serious neurological anomalies which may form a part of this syndrome include agenesis of the corpus callosum and medulloblastoma. According to Gorlin, an individual so afflicted may die early in infancy. ${ }^{79} 11$ There were no such findings in our patient. This case reinforces the idea that the dentist, especially an oral radiologist, pedodontist and orthodontist, has an important responsibility in early diagnosis and referral to other specialists for further evaluation. A definitive diagnosis of Gorlin-Goltz syndrome should be made by a multidisciplinary team comprising medical specialists and dentists. Life expectancy is not significantly altered but there can be substantial morbidity as a result of complications.

\section{Learning points}

- Local radiation therapy would not be advisable because of the tumour recurrence risk or because of the possible tumour growth.

- Patients should be educated about the hereditary nature of nevoid basal cell carcinoma syndrome, and they should have genetic counselling. In addition, with regard to skin cancer, patients should be advised to reduce ultraviolet light exposure, as well as advised about the relative risk and possible deleterious effects of receiving radiation therapy for their skin cancers or for other tumours as well.

- Topical agents such as imiquimod and 5-fluorouracil are available and have been approved for treatment of basal cell carcinoma in the USA. These medications have a lower cure rate than surgical therapy but may be useful adjuncts in patients with multiple lesions.
Contributors All the authors were involved in material collection and preparation of the manuscript.

Competing interests None.

Patient consent Obtained.

Provenance and peer review Not commissioned; externally peer reviewed.

\section{REFERENCES}

1 Ortega García de Amezaga A, García Arregui 0, Zepeda Nuño S, et al. Aguirre Urizar Gorlin-Goltz syndrome: clinicopathologic aspects. Med Oral Pathol Oral Cir Bucal 2008;13:E338-43.

2 Yordanova I, Gospodinov D, Kirov V, et al. A familial case of Gorlin-Goltz syndrome. Journal of IMAB - Annual Proceeding (Scientific Papers) 2007, book 1.

3 Lee B-D, Kim J-H, Choi D-H, et al. Recurrent odontogenic keratocysts in basal cell nevus syndrome: report of a case. Korean J Oral Maxillofac Radiol 2004;34:203-7.

4 Rosti RO, Aktas I, Kayserili $\mathrm{H}$, et al. Gorlin's syndrome: case report and management protocol. Balkan J Med Genet 2009;12:1.

5 Ahluwalia PKS, Ahluwalia TS, Singh G. Gorlin Goltz syndrome-a case report. J Ind Dent Assoc 2010;4:8.

6 Casaroto AR, Loures DCN Rocha, Moreschi E, et al. Early diagnosis of Gorlin-Goltz syndrome: case report. Head Face Med 2011;7:2.

7 Daramola JO, Komolafe OF, Ajagbe HA, et al. Syndrome of multiple jaw cysts, skeletal anomalies, and basal cell nevi: report of a case. J Natl Med Assoc 1980;72:3.

8 Muzio LL Nevoid basal cell carcinoma syndrome (Gorlin syndrome). Orphanet J Rare Dis 2008;3:32.

9 Hegde S, Shetty SR. Radiological features of familial Gorlin Goltz syndrome. Imag Sci Dent 2012;42:55-60.

10 Gupta SR, Jaetli V, Mohanty S, et al. Nevoid basal cell carcinoma syndrome in Indian patients: a clinical \& radiological study of 6 cases and review of literature. Oral Surg Oral Med Oral Pathol Oral Radiol 2012;113:99-110.

11 Stavrou T, Dubovsky EC, Reaman GH, et al. Intracranial calcifications in childhood medulloblastoma: relation to nevoid basal cell carcinoma syndrome. Am J Neuroradiol 2000;21:790-4.

Copyright 2013 BMJ Publishing Group. All rights reserved. For permission to reuse any of this content visit

http://group.bmj.com/group/rights-licensing/permissions.

BMJ Case Report Fellows may re-use this article for personal use and teaching without any further permission.

Become a Fellow of BMJ Case Reports today and you can:

- Submit as many cases as you like

- Enjoy fast sympathetic peer review and rapid publication of accepted articles

- Access all the published articles

- Re-use any of the published material for personal use and teaching without further permission

For information on Institutional Fellowships contact consortiasales@bmjgroup.com

Visit casereports.bmj.com for more articles like this and to become a Fellow 